\title{
Frankfurt's "German Library"
}

By WILHELM MOLL

$I^{\mathrm{N}}$ APRIL 1959 librarians in West Germany and everywhere in the free world celebrated the opening of a new library building in Frankfurt. The building is the new home of the Deutsche Bibliothek, or German Library, Germany's new national library and major bibliographical center.

It will be remembered that the former national library which was founded shortly before the outbreak of the First World War is located in Leipzig. Leipzig was for generations Germany's publishing capital and the location of a national library in that city was a perfectly natural development. Following the withdrawal of the American troops from Saxony in 1945, however, Leipzig became part of Soviet-controlled Germany and has remained so to this day. As a result all the activities of the Deutsche Buecherei, as the now East German library is called, have been subjected to the control of the Communist rulers, and librarianship, like other aspects of intellectual endeavor, has been placed in the service of their ideology. Only a few farsighted Germans anticipated these unhappy developments immediately following the German defeat and occupation in 1945. One of them was Hanns W. Eppelsheimer, then the director of the Frankfurt city and university libraries, who may be called the father of the new West German enterprise. He and several other librarians, booksellers, and publishers, including some who had left Leipzig when the American forces were withdrawn, advocated the establishment of a new library. Their efforts were crowned toward the end of 1946 when the American Military Government authorities permitted the formation of such
Dr. Moll is Assistant Medical Librarian, University of Kentucky.

a national collecting point and bibliographical center. Backing up the new venture were representatives of the West German booktrade and the indigenous governments of Hesse and the city of Frankfurt which provided modest quarters and funds. The final legal status of the new library is laid down in the bylaws of 1952 which endow the new institution with the rights and privileges of an independent foundation of the public law.

The main purposes of the library are stated in the bylaws as follows: "(1) The Deutsche Bibliothek shall collect .... preserve, make available, and arrange in accordance with scientific principles, German and foreign literature appearing within Germany and the German literature of foreign countries as of May 8,1945 . It shall lay the foundations for a national bibliography." In accordance with these principles, the Deutsche Bibliothek has attempted to gather almost all German-language publications (a few types of publications are excepted) appearing anywhere in the world after May 8, 1945. Included are trade as well as official publications, dissertations, and society publications. They are furnished by publishers and printers on a voluntary basis, except for federal documents which must be deposited in accordance with a recent (1958) decree.

Library statistics attest to a steady growth of the new library. While in $1946 / 47$, the first year of operation, there were a little over 10,000 titles in the Deutsche Bibliothek, by the end of 1959 


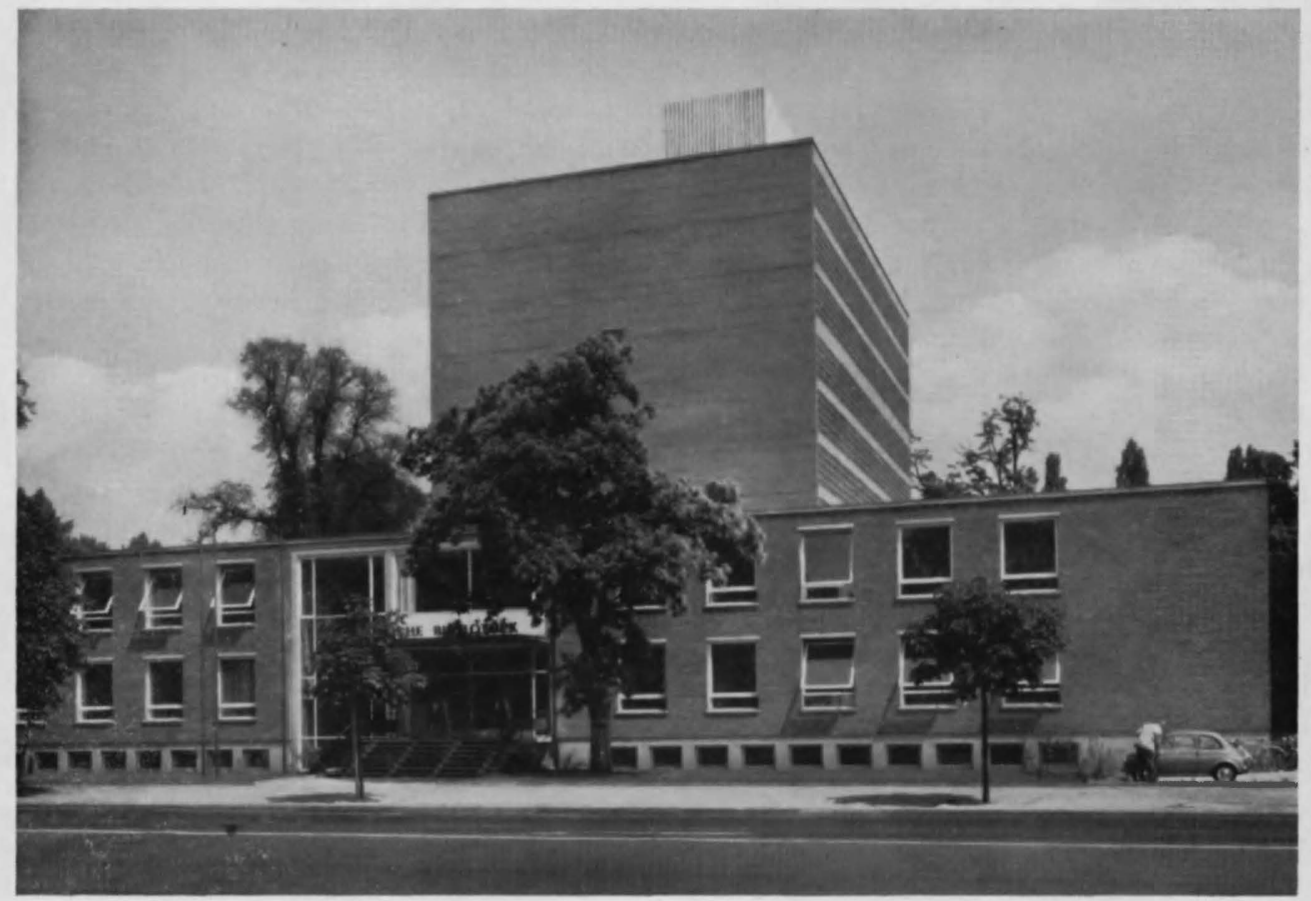

View of the new Deutsche Bibliothek building.

this figure had risen to 227,924 titles (and almost 300,000 volumes). Added to this are 17,029 periodicals and 71,496 dissertations. Also in 1959 the library was exchanging its major bibliographies with 91 foreign libraries. Although the library is primarily charged with the preservation of its materials close to 26,300 patrons used some 42,000 volumes in 1959 , and it is expected that the use of the materials will rise further in the following years.

In this connection, Professor Kurt Koester, the director of the Deutsche Bibliothek noted in a private communication to the author: "[The move into the new building] provided us for the first time with a reading room with a capacity of 75 seats which is particularly important to us, because as an archival library we are not permitted to loan our materials for use outside of the building. ... This improvement explains, among other things, the increase of the number of users which has risen from 7,000 in
1958 to 26,300 during the first seven months [of 1959] since moving into the new quarters."

An important role is played by the reference staff of nine members, who in 1959 , answered on an average of 6,150 inquiries monthly. It is aided in its efforts by a small, but growing reference collection of 7,724 volumes.

Rounding out the holdings are two special collections, the Library of the Emigration, comprising works by German writers who were forced to flee Germany because of Hitler's accession to power, and the Archives of Unpublished Scientific Publications, Archiv ungedruckter wissenschaftlicher Schriften.

Probably the most significant contribution to scholarship is the series of national bibliographies being issued currently by the library. They go under the title Deutsche Bibliographie and include German-language publications published within the country and in foreign countries. Beginning in 1947 there appeared 
weekly, classified bibliographies, Woechentliches Verzeichnis, which four years later were cumulated into semi-annual bibliographies, Halbjahresverzeichnis, arranged alphabetically by authors. A third step in this series are national bibliographies which are similar in arrangement to the semi-annual bibliographies and which include publications for periods of five years, Mehrjahresverzeichnis. The first in this series comprised publications for the years 1951-1955. The latter aims to include not merely publications in the actual possession of the Library, but also German trade publications of foreign countries. A separate periodicals bibliography for the years 1945-1952, Zeitschriften was completed in 1958. It will be the first in a new series of periodicals bibliographies. Another special bibliography for official publications was prepared for publication in 1960 . Finally, mention should be made of the bi-monthly Das Deutsche Buch, a selective bibliographical bulletin which is distributed primarily among scientific institutes, libraries, booksellers, publishers, and German diplomatic missions.

In conclusion due credit should be given to the staff of the Deutsche Bibliothek. There were only four employees in 1946 when the library was first organized. At the end of 1959 there were 137, including ten laborers and fourteen trainees. Compared to the size of staffs of other large national libraries and bibliographical centers the number of librarians and clerical workers is small indeed. Their contribution to librarianship under difficult post-war conditions has secured them a prominent place in the library world.

\title{
The Library Technology Project
}

\author{
(Continued from page 368)
}

cent years of new materials and methods for binding, it has become desirable to develop performance type standards. Similarly, it has become apparent that the various end-uses of many library materials may require more than one type of binding.

Some of you have already been visited by members of the survey team for this project.

None of the programs I have just described has been completed. In fact, one of the first lessons we had to learn was how long it requires to obtain final results in such cases. The program on quick laminating equipment for example, was begun in September 1959, but it will be March 1961 before the report is published. Since this first venture, we have learned several things that will help speed such programs, but there is still an irreducible minimum for many testing projects.

We expect to publish reports on certain adhesives, on pressure sensitive tapes, on laminating equipment, and on the circulation control study during the spring. Reports of other programs will follow as rapidly as possible.

If the project is continued it will be able to conduct many more of these basic studies that will free librarians from some of their time-consuming administrative problems. 